\title{
How does market making affect industrial relations? Evidence from eight German hospitals
}

\author{
Ian Greer \\ Work and Employment Relations Unit, University of Greenwich \\ Thorsten Schulten \\ Wirtschafts- und Sozialwissenschaftliches Institut, Hans-Böckler-Stiftung \\ Nils Böhlke \\ Die Linke, Landtagsfraktion Nordrhein-Westfalen
}

Final submission to the British Journal of Industrial Relations, September 2011

\begin{abstract}
The introduction of market mechanisms matters for industrial relations. In the German hospital sector, national liberalization policies have put immense pressure on local management and worker representatives and led to the growth of a low-wage sector. In case studies of eight hospitals, we find some locales where market making has led to union revitalization and mobilization, but this effect varies. Using an eight-way comparison, we infer a configuration of three aspects of the local political economy labour markets, politics, and codetermination rules - that together provide a well fitting explanation for both variation and change.
\end{abstract}


In the 1980s and 1990s, industrial relations writers asked why German labourmanagement partnership was resilient in the face of changing world markets. The answer was that institutions mattered: nationally specific rules regulating in-firm worker participation (codetermination) and wages (coordinated collective bargaining) produced mutual gains for workers and employers on a mass scale (Turner 1991). In recent years, however, Germany has gone from being one of the most equal societies in Europe to having an incidence of low-wage work close to that of the UK (Bosch and Weinkopf 2008). Much of this low-wage work is nominally organized, with $34 \%$ of workers in the lowest income quintile covered by collective agreements in 2008 (Bispinck et al 2010). If, as theorists argue, formal institutional change has been gradual and has served to shore up the system's basic logic (Streeck and Thelen 2005), why have these outcomes changed?

In this paper we explore these shifts in the German hospital sector. More than other countries, Germany has increased the scope for hiving off groups of hospital staff into low-wage collective agreements for support services (Grimshaw et al 2007), to defect from collective bargaining altogether (Böhlke and Schulten 2009), or shift from one set of co-determination rules to another. This institutional disorganization has taken place against the backdrop of an overall squeeze on resources in the public sector and a shift toward private ownership in hospitals, both resulting from the introduction of market mechanisms into health care funding formulae. Unions and civil society have responded by mobilizing against privatization and the derecognition of sectoral 
bargaining (Greer 2008) and by organizing within the private-sector co-determination framework, which is formally stronger than its public-sector counterpart.

We argue that, in order to understand the changes of the past decade in Germany, theory needs to depart from the standard toolkit of comparative institutionalism and turn to issues of market making and local political economy. In response to the relentless liberalization of the sector, we observe a wide variation in the functioning of worker representation. ${ }^{i}$ Using an eight-way comparison, we find that variation is due to differences in local politics and labour markets, as well as sector-specific codetermination rules.

Our research into the sector draws on publicly available data on the sector and indepth interview-based qualitative research on eight hospitals, carried out between 2003 and 2009. Our research began in 2003 as an exploration of a campaign in Hamburg by Germany's main union in health care, vereinte Dienstleistungsgewerkschaft (ver.di) against a large-scale privatization initiative. We also conducted interviews at the national level and at two other municipal hospitals, Chemnitz (in the east) and Stuttgart (in the south), to assess the representativeness of the Hamburg case. In 2006-8 we added to our sample municipal hospitals operating under centre-left local governments in Dortmund and Berlin and the largest acquisitions of the two other large for-profit players: Helios (Erfurt's municipal hospital) and Rhön (the Gießen-Marburg university hospital). At each site we interviewed works councilors and staff of the main union, ver.di, and at most sites we also interviewed managers, politicians, and union allies. We triangulated this information using the trade press, collective agreements, consultants' reports, union newsletters, newspapers, publicly available statistical data, and interviews with national 
officials of ver.di and the physicians union, the Marburger Bund. We conducted 60 interviews with 57 individuals, with more interviews at the hospitals we had been studying the longest, including 6 national-level experts. In January 2009 we held a 2-day conference in which worker representatives discussed their work and debated our findings. Participants included representatives from ver.di's national and regional offices and works councilors from Hamburg (Asklepios), Stuttgart (public), Gießen-Marburg (Rhön), and Berlin-Buch (Rhön) (see table 1).

\section{(Table 1 about here)}

This paper begins by reviewing recent developments in institutional theory and German industrial relations. Second, we provide an overview of changes in the terms of competition in the hospital sector and their effects in the workplace and on collective bargaining. Third, we examine workplace restructuring and worker representation in the eight case studies. Fourth, we re-examine the case studies in terms of the local labourmarket, political, and institutional factors that mediate the relationship between liberalization and labour-management relations. We conclude with a discussion of the theoretical and policy implications.

\section{Market making and institutional theories of industrial relations}

The story of German hospitals is theoretically unlikely, because it is about employers covered by collective bargaining, subject to other forms of non-market regulation, not subject to global competition, who nevertheless compete on the basis of labour costs. Despite widespread acknowledgement of decline in union membership and collective bargaining coverage (Hassel 1999), German industrial relations is still used as a defining 
instance of rule-based obligatory institutionalized behaviour. Streeck and Thelen (2005), for example, argue that in Germany, '.. an employer who turns his shop into a "unionfree environment" will not just be reproached by the unions he has locked out, but also by the courts that will remind him of the obligations the law of the land imposes on an employer of labor as a matter of legal duty' (15). A second surprise is the union response, which includes localized mobilizations that resemble what US scholars call 'social movement unionism'. Theory predicts that German unions have incentives to use social partnership to pursue their goals due to their institutionalized leverage (Baccaro et al 2003; Frege and Kelly 2004). In order to understand the gap between theory and reality, it is worth examining the two main mechanisms in this literature that cause capitalist diversity and inform standard narratives of German industrial relations: institutional complementarities and societal embedding.

Most institutional theories contain a notion of systems with elements that coevolve in a coherent and functional way. For Hall and Soskice (2001), for example, complementarities between institutional systems governing such activities as training, corporate governance, and wage setting create stability and difference in national institutions. The coherence of these interacting systems produces comparative advantages for employers, which employers have an interest in preserving. The result should be 'dual convergence': coordinated market economies such as Germany will become more coordinated and liberal market economies such as the US will become more liberal.

Events in Germany since the late 1990s have not confirmed this prediction, spurring a theoretical concern in institutional change. The institutions of corporate 
governance were subject to major revision (Höpner 2007), and collective bargaining experienced a functional shift away from redistribution and towards retaining jobs and investment (Rehder 2003). Drawing on the Polanyian thesis of societal embedding - that societies tend to devise measures to counter the perceived destructive effects of the market - this group of writers argues that change has happened, but that social institutions have made it 'path dependent' (Streeck and Thelen 2005). Liberalization entails neither wholesale convergence on a neoliberal model nor retention of the old system, but rather, 'strategic behavior on the boundaries of institutions [leading] to incremental forms of institutional change' (Sako and Jackson 2006: 563).

For some of these writers, and for us, a defining feature of liberalization is the making of markets. But what do we mean by the market, and how can one be made? We speak of the market in a sociological sense (e.g. Krippner 2005), as a set of exchanges where more or less commodified 'things' are bought and sold. Every market is structured by government regulation, self-regulation, and participants' norms, and is as a result more or less governed by prices as opposed to non-economic concerns. Of interest to us is the kind of market that emerges as a deliberate choice by the state: a choice to use the price mechanism more and to ignore certain other non-economic concerns. In German hospitals, where there is little tradition of free competition, and where restructuring is politically sensitive, the state has retained its strong roles in planning and pricing and used these roles as levers to promote marketisation.

While the social effects of marketisation have been peripheral to the sociology of markets (Beckert 2007: 17-18), they have shown up in much empirical industrial relations literature. For example, market mechanisms are important in the 'new public 
management' internationally (Kirkpatrick and Martínez Lucio 1996) and in Germany are increasingly used by large firms to allocate resources internally (Brinkmann and Dörre 2008). Market making is associated with Reaganite or Thatcherite politics; but it is also central to the EU's methods for securing the free movement of goods, services, capital and labour (Lillie 2010). The creation of markets matters centrally in explaining how outsourcing and other forms of vertical disintegration affects industrial relations in Germany (Doellgast and Greer 2007).

As in most countries, German unions are active in 'embedding' markets, i.e. preventing them from eroding the terms and conditions of employment. Conversely, the complexity and uncertainty caused by marketisation forms the background of most of the contemporary literature on unions. They face crisis, existing patterns of action seem untenable, and new leaders with different outlooks implement, with more or less success, new strategies (Nissen 2002). This adaptation can take the form of the re-establishment of bargaining at the new scale of the market, as in Commons' (1909) narration of the rise of a national market for shoes and a national union for shoemakers or Lillie's (2006) case of global collective bargaining for seafarers as a response to Flags of Convenience.

Unions can also adapt by changing the way they intervene in the complex mechanisms of state, local and national government, in legislation, administrative decision-making, or the judiciary (Benz 2005; Katz et al 2003). While traditions of national industrial relations still sometimes matter for how unions respond to liberalization (Doellgast 2009; Holst 2008), this has not prevented local experimentation by German trade unions (Dörre and Röttger 2006; Turner and Cornfield 2007; Turner 2009). These responses have been shaped by the character of local civil society (Locke 1992), conflicts or communities of 
interest (Tattersall 2005), or ideology and power relations within firms and sectors (Anner 2003).

The dynamics of liberalization can be seen in Europe, where courts and administrative bodies have promoted more open international competition in markets for services. One result in Germany has been the selloff of public service organizations in sectors such as energy, telecommunication, postal services, and public transport. In the absence of sectoral collective agreements to regulate new competitors, to paraphrase John Commons, the wage bargain between workers and employer is increasingly determined by the price bargain between producer and customer, leading to downward pressures on wages (1909).

Unlike Commons' shoe industry (and unlike contemporary sectors subject to global market pressures), the salient changes in German health care not a geographic extension of the market, but rather a functional extension of market mechanisms into new areas of activity. In both instances, intensified competition is the result. But here, marketization is a policy of managers and politicians to govern differently, rather than a loss of control by sovereign rule makers due to the actions of distant competitors (Lillie 2010; MacKenzie and Martínez Lucio 2005). Although marketization poses a threat to workers and unions, there is no obvious scale at which unions could re-establish control analogous to the national shoemakers union or the global collective agreement for seafarers. Local union responses to intensified competition vary, and this paper examines how and why. 


\section{The local effects of national market making: our findings and argument}

The finding of change and diversity may in itself seem surprising, given German unions' and employers' reputation for hierarchical national coordination. Why is there so much variation and change? The answer can be found in the features of local context that support or undermine different patterns of labour-management interaction.

We examine local industrial relations in terms of the character of worker representation. While all works councils in the sample were led by ver.di members, and could therefore be considered trade unionists, they behaved in diverse ways. Some were working in close consultation with management, with a minimum of conflict, accepting responsibility for the effects of change, but receiving additional rights and resources; in keeping with other writers, we call this 'co-management' (Rehder 2006). Others had good management access, which they augmented with worker mobilization. This can be called Konfliktpartnerschaft, and is a well established pattern in German industrial relations, in both the east and west (Müller-Jentsch 1999). Third, we met trade unionists who were excluded from decision making and had to pressure management and politicians from the outside, through coalition building, member mobilization, and an appeal to broader social issues; this can be labelled social-movement unionism (Greer 2008). Finally, we met trade unionists, mainly in the East, who had a resigned attitude towards exercising power or seeking influence and exercised their codetermination rights primarily in order to gather information and provide better advice to workers. This approach we label quiescence (table 2).

(Table 2 about here) 
Our explanation (table 3) focuses on three aspects of the local political economy, which on their own are insufficient in explaining this variation, but in combination supply a well fitting explanation for the observed variation and change. First, codetermination rules, which vary according to whether the hospitals are governed by non-profit, forprofit, or public sector law, shape worker representatives' access to management. However, they do not assure union power, because they are subject to change in line with the decisions of state and local politicians, and trade unionists are not always able or willing to mobilize workers in support of demands. Second, the level of local unemployment affects unions' abilities to mobilise workers. Four of the hospitals we studied are in the places where unemployment is very high and four are in places where it is relatively low, and mobilization is more common in the latter group than in the former group. Third, channels of influence in local government may provide access to decision making despite weak codetermination rights or mobilization capacity. Some cities in our sample are governed by a strongly entrenched union-supported centre-left establishment, while others are governed by conservatives who tend to freeze trade unionists out of decision making. These channels, however, do not ensure that social partnership will work smoothly; weak codetermination rights and a shift in the governing coalition can both undermine social partnership.

(Table 3 about here) 


\section{Liberalization and working conditions in German hospitals}

Germany is an especially far-reaching case of hospital liberalization. No other European country has privatized a larger percentage of hospitals (Böhlke and Schulten 2008) or seen such fragmentation in hospital collective bargaining (Grimshaw et al 2007).

Sickness and health are not commodities that can be bought and sold, and health care is an existential good that Germany, like every society, provides in some form independently from the patient's ability to pay (Deppe 2002). While there is a strong element of patient choice, the real powers in this so-called 'dual system' are the two funders: the Länder, who are also responsible for planning and investment, and the (mostly quasi-public) health insurers, who cover hospitals' operational costs through reimbursements. This organizational landscape is structured by the Social Security Code (Sozialgesetzbuch $V$ ) and the Hospital Financing Law (Krankenhausfinanzierungsgesetz).

In the beginning of the 1990s, lawmakers began to introduce market mechanisms into the statutory framework, in order to encourage the 'economization' of hospitals. Their aim was to cap costs in the face of new medical technology and rising life expectancy. Because the health system depends on employer contributions to insurance funds, the fear was that excessive growth in healthcare costs would have undermined the international competitiveness of the German industry. Thus, although markets in the hospital industry - for patients, reimbursements, and investment capital - remained domestic, reformers justified their actions as a necessary adaptation to globalization.

One crucial area of reform was hospital financing, or more specifically, the decoupling of payments to hospitals from the cost of provision (Simon 2007a). In the 1993 Health Care Structure Act, lawmakers abolished the principle of full-cost recovery, 
introduced a cap on increases in reimbursements to any given hospital (regardless of the service provided), and created new mechanisms for hospitals to operate under budget surpluses or deficits. In 1996, lawmakers added a component of reimbursement to take the specific diagnosis into account, and in 2000, they took this principle further. Using the argument that per-diem payments created incentives for hospitals to unnecessarily extend patient stays, lawmakers adopted a version of an Australian system of standardized payments called Diagnostic Related Groups (DRGs).

Although the DRG system was not completely implemented until 2009, its effects on the management of hospitals were clear from the beginning (Brandt and Schulten 2008a; Wendl 2008). By standardizing payments according to the average 'production costs' of each diagnosis, the system made it difficult for hospitals to hide their costs from the insurers and easier for insurers to extract cost reductions for lucrative diagnoses that had previously subsidized other parts of hospital operations. This put pressures on hospitals to reduce costs by increasing patient-to-staff ratios, while competing for patients with relatively lucrative diagnoses. Under the threat of bankruptcy, hospitals operating under deficits faced increasing pressure to restructure; meanwhile, their competitors with surpluses began to save up investment capital and expand. For local governments with scarce resources running loss-making hospitals, privatization thus became an attractive solution.

The other side of the dual financing system - investment - reinforced these pressures, especially the trend toward privatization. Between 1991 and 2008, the share of GDP invested in the public sector dropped from $2.6 \%$ to $1.5 \%$, putting Germany in second to last place among EU member states (Anonymous 2009). The hospital trade 
association estimates the resulting backlog of investment at around $€ 50$ billion (Blum and Offermanns 2009); some economists estimate it at $€ 100$ billion (Simon 2008). Given the government's reluctance to increase taxes, the financial tug-of-war between state and national government built into the federal system, and the overall limits on government borrowing set by the 'European Stability and Growth Pact', Länder turned to privatization as an alternative source of investment capital.

Until the 1990s most German hospitals were operated either by local government or not-for-profit organizations (mainly churches), while for-profit hospitals played only a minor role, with smaller, specialized clinics. The first wave of privatization began in 1991 in the eastern Länder, where planners created a mixed economy of hospitals with less government ownership than in the west. After 2000, a second wave of restructuring occurred, this time in the west, which included the privatization of some of the largest municipal hospital systems. The share of hospitals in private ownership increased from $15 \%$ in 1991 to $33 \%$ in 2010 (figure 1). At first, the targets of privatization were smaller hospitals with under 100 beds, but as the private hospital chains expanded, so did the average size of private hospitals. From 2002 to 2010 the share of beds in these hospitals increased from $9 \%$ to $17 \%$ (Anonymous, various years), and in 2005, of the more than 65,000 beds controlled by private companies, more than half were controlled by three companies, Asklepios, Rhön, and Fresenius (the parent company of Helios), each with just over 10,000 (Brandt and Schulten 2008a). Meanwhile, hospitals that remained stateowned were merged into independent subsidiaries with a private legal form, granting hospital administrators more autonomy and reducing the day-to-day involvement of state and local government. The share of beds at public hospitals with a private legal form 
increased from $27 \%$ to $57 \%$ from 2002 to 2009 , while the figure at closely held public hospitals declined from 54\% to $16 \%$ (Anonymous, various years) (figure 1).

\section{(Figure 1 about here)}

Since more than $64 \%$ of hospital expenses are spent on personnel (ibid.), cost pressures have had several implications for industrial relations. One result has been work intensification. Between 1995 and 2005 the number of hospital employees dropped by 85,000 full-time equivalents (FTEs). Doctors were the only group that saw an increase, of about 19,000 FTEs, while all other groups, including nurses and assistants, experienced cuts (Simon 2007b). One method of reducing staff has been the outsourcing of support services such as cleaning, cooking, driving, and information technology systems. As the number of employees has declined, the number of 'cases' has increased (Figure 2), leading to higher patient-to-staff ratios (Marrs 2007). At privately owned hospitals this trend has gone especially far: while an average full-time nurse in the private sector was responsible for 505 occupied bed-days in 2007, the corresponding publicsector figure was 421 . A private-sector doctor, on average, treated $23 \%$ more patients than a public-sector doctor, and the difference is even greater for physiotherapists, psychologists, pharmacists, and social workers (Böhlke and Schulten 2009).

(Figure 2 about here) 
Cost pressures have also led to the fragmentation of collective bargaining. Before liberalization, all public hospitals were covered by the public sector collective agreement, known as the Bundesangestelltentarifvertrag (BAT) and in 2005 reformed as the Tarifvertrag des öffentlichen Dienstes (TVöD), and most not-for-profit hospitals oriented their working conditions to those in the public sector. As for-profit chains have bought hospitals, they have shifted their staff into company- or hospital-level agreements or unilaterally implemented pay freezes. Consequently, in 2007, labour costs per employee at for-profit hospitals were $4 \%$ lower than in the public sector, with greater savings for nurses (9\%) (Böhlke and Schulten 2009: 111). One survey found that 24\% of employees in private hospitals had no collective bargaining at all, and the wages of only about a third were oriented to TVöD (Anonymous 2007). Other private hospitals have used a collective agreement with lower rates of pay signed by an association of private hospitals and a small union unaffiliated with the mainstream trade union movement (Gröschl-Bahr and Stumpfögger 2008). ${ }^{\mathrm{ii}}$

Intensified price-based competition has had implications for collective bargaining in public sector hospitals. One common cost-cutting measure in the public sector has been to shift staff in support services into subsidiaries with low-wage collective agreements for cooking, cleaning, security, or transportation (Jaehrling 2008). Another option is the use of hospital-level hardship agreements ('Notlagentarifverträge'), under which pay can be reduced by up to $6 \%$ in exchange for employment security. A third option is derecognition of collective agreements; this is rare at publicly owned hospitals, but has taken place (as in Chemnitz, described below). In cases of privatization or outsourcing, German law protects the pay and working conditions of staff for one year; 
wages and working conditions afterwards depend on collective or individual negotiations between staff and employer.

The story, however, is not merely one of disorganization and decline: ver.di membership has increased or been stable in the hospitals we have studied. The physicians union Marburger Bund grew from 70,000 to 110,000 members after a 2005 strike, giving it a membership density of $70 \%$. Because of the implications for pay, work tempo, and service quality, hospital restructuring often leads to conflict at local level; every case of hospital privatization we know of has faced serious opposition. This local movement may be influencing national events: while ver.di had little success in influencing the design of markets in the 2002 reforms, in 2008 it worked in a broad health-care industry coalition to mobilize 130,000 workers and win a $€ 3.5 \mathrm{~b}$ increase in hospital funding for 2009. Liberalization thus presents an opportunity for union revitalization, nationally and locally.

\section{Local trade union responses}

Compared to IG Metall, the union most commonly studied in the English-language literature on Germany, ver.di is an extremely diverse organization. It was formed in a 2001 merger of five service-sector unions, two of which were present in hospitals (the white-collar DAG and the public-sector ÖTV), making it Germany’s largest servicesector union. Ver.di's structure - a 'matrix' intended to preserve sectoral identities, while

integrating administrative functions - has two cross-cutting dimensions of relevance here: (1) a sectoral dimension of 13 broad Fachbereiche, including FB3: Churches, Social Services, Welfare and Health Care, and a much larger number of narrower Fachgruppen, 
including one within FB3 for hospitals; (2) a geographic dimension of 11 state-level Landesbezirke, plus local Bezirke and Ortsvereine. [Adding to this complexity are two additional dimensions: Personengruppen (e.g. gays, youth, unemployed), which are nominally represented at every geographic level, and Ressorts (e.g. social and health care policy), and departments covering specific issues across the whole organization]. The advantage of this fragmented structure is its relative openness to innovation within a locality or a sector (Greer, 2008); its disadvantage is the difficulty of between-sector coordination in national campaigns (Doellgast and Holtgrewe, 2011).

Local trade unionists have not been completely on their own. In some local cases, such as Hamburg and Stuttgart, battles around hospital restructuring were important early moments defining the local Bezirk's identity and strategy; in these cases material support came from the national union. Hospitals have become increasingly important in national public-sector strikes, as the large blue-collar-dominated enterprises that were the old ÖTV's main source of leverage have been privatized or taken out of the national public-sector bargaining framework. Likewise, establishing collective bargaining and codetermination at for-profit chains has become an important task for the national staff of FB3, as has the hospital financing campaign. Compared to most of the public sector, ver.di has been successful at the hospitals we have visited in avoiding derecognition of collective bargaining. Only in Chemnitz has the employer lowered the wages of core workers substantially below the rate the TVöD, although all hospitals have implemented lower-paying collective agreements for some outsourced support services. We now turn to the four patterns of worker representation. 


\section{Co-management}

In Dortmund, Berlin-Vivantes, and pre-2001 Hamburg, restructuring was negotiated with a minimum of conflict. Some of these workplaces had a history of mobilization, as in Hamburg, where local trade unionists had occupied a hospital slated for closure in the mid-1990s, or a strong mobilization potential, as in Dortmund, where union density approached 40\% (in Berlin-Vivantes and pre-2001 Hamburg, density ranged between 10 and $15 \%)$.

All of these workplaces went through restructuring starting in the mid to late 1990s. In 1995, for example, Hamburg turned its hospitals into a separate state-owned enterprise, Landesbetrieb Krankenhäuser (LBK) Hamburg, closed a historic hospital, and set about eliminating 3000 out of 15,000 jobs. Berlin's state owned hospitals were merged as Vivantes in 2001 and given a private legal form; afterwards, management eliminated nearly 2000 out of 12,000 jobs and outsourced most support services. When Dortmund's hospitals received a non-profit legal form in 1999, management moved to reduce costs through changes in procurement, rather than personnel cuts.

In each case, the union's influence depended on personal ties with policymakers. In Hamburg and Dortmund, these channels of influence ran through the Social Democratic Party (SPD), which had dominated municipal politics continuously for most of the post-WWII era in close cooperation with trade unions. Vivantes was created by a 'grand coalition' (SPD and conservatives) in Berlin's local government; here, the union also worked constructively with conservative politicians. Key managers were part of these networks. In Dortmund and Berlin, the worker-nominated Arbeitsdirektor was built into the hospitals' enabling legislation. In Hamburg, the arrangements were less formal: 
like many of his trade-union counterparts, the director of the hospitals was an active SPD member. Furthermore, these cities' unions were represented directly on the city councils by staff and activists.

Worker participation in restructuring these hospitals extended well beyond the minima stipulated by law, which in Hamburg and Dortmund were relatively weak. Hamburg, Dortmund and Berlin all went through a change of legal form under comanagement, with the aim of cutting costs and reducing staff numbers. The negotiations over this process went far beyond bargaining over the effects on staff. In Hamburg and Dortmund, workers won rights in addition to the legal minima under their legal forms. In Hamburg, management agreed with the union on a committee structure for negotiating the restructuring of departments, complete with an independent consultant to support worker representatives, to augment the relatively weak public-sector codetermination framework. In Dortmund, the enabling legislation for the restructuring stipulated codetermination practices reflecting those under the private-sector framework, despite the non-profit legal form, and a 2005 collective agreement extended these practices. In all three cases, strong political influence led to a strengthening of codetermination practices in the newly restructured workplaces, reinforcing the pattern of co-management.

These worker representatives thus enjoyed long-lasting close relationships with management and local politicians. However, co-management was not to last in Hamburg and seems to be coming to an end in Dortmund. In Hamburg, the immediate cause of change was a switch in local government to one willing to ignore trade unionists. The more general cause, however, was the squeeze on resources associated with the liberalization process: Hamburg had massive pension liabilities, and Dortmund operates 
at a loss and faces delays in receiving investment from the state government. In Hamburg, local politicians were not interested in union offers for a compromise, making social partnership impossible. In Dortmund, the local political establishment came under pressure due to funding delays and the categorical refusal of wage concessions for physicians by the Marburger Bund. Autumn 2008 seemed to signal the end of business as usual in Dortmund: ver.di activists and the DGB set up a local coalition dubbed 'ProKlinikumDo' which used media work and public demonstrations to defend the hospitals.

\section{Social movement unionism}

In Stuttgart and post-2001 Hamburg, change has been negotiated against a backdrop of worker and community mobilization. While in Hamburg this strategy represented a change for the union, in Stuttgart it reflected a history of exclusion from politics. The link with civil society required unions to engage with issues beyond the defence of jobs and collective bargaining, such as public service quality, democracy, and the untranslatable German value of Menschenwürde.

The majority buyout of LBK-Hamburg by Asklepios Kliniken was the largest hospital privatization in German history. After the Conservatives won the elections in 2001, they immediately pushed for privatization. In this situation the newly established union, ver.di, initiated a referendum, together with a wide range of allies from civil society. Although the referendum was successful and spilled over into a second campaign to make ballot initiatives legally binding, a majority stake was sold to Asklepios. After an 18-month dispute, which included a series of demonstrations and work stoppages, an 
agreement was signed in 2007 that linked wages and working conditions to the national public-sector framework.

In Stuttgart, by contrast, worker representatives had no history as co-managers. They did have a long history of battling the conservative-dominated local government over hospital restructuring. Nor did they have privatization to contend with: Stuttgarter Kliniken was created by a merger in 1999 and is a closely held municipal agency. Shortly after the formation of ver.di in 2001, the union and works council ran a campaign against the concentration of cooking in a single location. Called 'no to the cooking factory', this campaign was coordinated closely with the Catholic industrial chaplaincy, and highlighted the difficult working conditions of the low-paid, mostly female, staff. Two years later, the city announced its intention to close three hospitals and concentrate activity on one large campus, in hopes of finding efficiencies and reducing staff numbers. After demonstrations involving a wide range of local activists, the city agreed to consider ver.di's alternative concept. In 2005, the union followed up with a successful protest against introducing a private legal form, fearing that such a move would make the hospital susceptible to bankruptcy and privatization. That same year, workers struck for 14 weeks to prevent the city from leaving the employer's association, and as the largest part of the city government, the hospitals played a key role.

While worker participation was relatively weak at these hospitals, ver.di seemed to be in the process of establishing its influence. In Stuttgart, pressure is building on the hospital management to reduce debt, and worker representatives have been in a series of negotiations to minimize the pain to workers. Meanwhile, at Asklepios, ver.di is involved in setting up national codetermination, not only for Hamburg, but for other locations. In 
both cases, campaigning has also led to an increase in union membership, in Hamburg, more than doubling since privatization to more than $30 \%$.

In Stuttgart and Hamburg, a social-movement approach developed over a long period. Both places were the sites of strikes in response to employer challenges to the framework of public-sector collective bargaining, and union membership grew as a result. If ver.di persists, new insider channels of influence may be created. If so, it will be different from co-management, because it will be more tentative on the union side, and shaped by 7-10 years of conflict.

\section{Konfliktpartnerschaft}

At the two university clinics, Berlin-Charité and Gießen-Marburg, we observed a pattern of participation backed up with mobilization, with neither having the intensity seen in comanagement or social-movement unionism. At first sight, these seem to be cases of social-movement unionism. However, these mobilizations are much closer to traditional German industrial relations, because coalition work is not central to the mobilizations, and because conflict is used to exploit, strengthen, or expand existing channels of influence. Union density here is around $10-20 \%$ and tends to increase in times of conflict. Universitätsklinikum Gießen und Marburg was the first privatized university hospital in Europe; it was created through a merger of two university clinics and sold to the Rhön Kliniken AG in 2006. The merger was a necessary step to find an investor who was willing to buy the heavily indebted clinic in Gießen. While trade unionists resisted privatization, especially in Marburg, they accepted an invitation by the conservative government to participate in a planning group. After the clinics were privatized, ver.di 
took industrial action to achieve a collective bargaining agreement. This mobilization built on a strong local tradition of trade unionism that had developed in a context of good political connections and weak codetermination rights. Under the post-1999 conservative-led and pre-1999 SPD-led governments alike, the union faced pragmatic politicians willing to listen, but very weak workplace-level co-determination rights.

Like Vivantes, Charité is publicly owned and located in Berlin, but since it is a university clinic, codetermination rights are significantly weaker. It is the product of a merger in 2003, under a new left-wing coalition government, which brought together the university clinics in West and East Berlin into a single organization. Works council members have relatively little access to the management and thus cannot negotiate over changes as effectively as their colleagues at Vivantes. In 2005 and 2006 there were several brief 'warning strikes' and rallies to use the standards of TVöD, rather than the less generous terms and conditions of the Land Berlin, and, without mobilizing much public support, worker representatives achieved most of their goals.

At Berlin-Charité and Gießen-Marburg, worker representatives have not faced the exclusion from management and politics seen in Stuttgart and post-2001 Hamburg. Nor is management as committed to intensive worker participation and collective bargaining as in Dortmund or Berlin-Vivantes. True to a traditional industry focus, workers are mobilized mainly around workplace issues.

\section{Quiescence}

In Erfurt and Chemnitz, two eastern cities with high unemployment rates and weak traditions of trade unionism, we observe quiescence within the hospitals. Here, works 
councillors - most of whom are ver.di members - tend to play a social-work role, rather than mobilizing or participating in detailed consultations over the management of change, and neither hospital belongs to the public-sector employers association.

Klinikum Chemnitz is owned by the city government and, since 1994, has been run under a non-profit legal form. Despite the presence of key trade unionists in the three largest party groups on the city council and a long-serving SPD mayor, trade unionists have had little influence in the management of the hospital. According to worker representatives, employees are satisfied with having a job and unwilling to take action for better working conditions or higher wages. Furthermore, the mayor and administration are highly effective in cutting costs and winning support for their restructuring plans in city council. Hence, management has been able to outsource support services without union resistance, and in 2005 left the employers association and unilaterally introduced lower pay grades for most new employees.

At first sight Erfurt seems very different: not only is the Klinikum Erfurt in the private sector, but it became Germany's first large case of privatization when it was bought by Helios in 1996. Although worker representatives formed an alliance with groups in civil society to oppose privatization, the coalition collapsed when it failed to prevent the sale. Helios began cutting costs by changing its procurement practices, and later moved on to reducing staff. Since there were no mandatory redundancies, works council members found little basis to organize resistance. In January 2007 Helios signed a national company-level collective agreement, negotiated with national ver.di staff. Under this new framework, Erfurt's pay scales introduce East-West parity earlier than the TVöD, with little downward deviation from the national agreement. 
Why is quiescence specific to the East? Our interviewees pointed to unemployment rates between 15 and $20 \%$ and weak union influence in local government. Surprisingly, low union membership is not always the issue: in Chemnitz, density is around a quarter, higher than some of the western hospitals. It may be that, in the event of an economic upturn or the retirement of workers, managers, and union staff educated under communism, worker representatives in Erfurt and Chemnitz could become more assertive.

\section{Explaining diversity}

Why do local industrial relations vary when market mechanisms are rolled out on a national scale? In local polities closed to union influence we saw either quiescence or social-movement unionism, depending on labour-market pressures. In more open local polities, not all of which were led by centre-left parties, we were surprised by the variation. Ownership also mattered, because it determined the applicable statutory framework of co-determination. We observed Konfliktpartnerschaft under conditions of weak codetermination rights, i.e. under traditional public-sector co-determination rules, and (with one exception) co-management under conditions of strong codetermination rights, i.e. under private-sector co-determination practices. In this sense, these three variables are inseparable characteristics of the local context that shape industrial relations under liberalization. 


\section{Codetermination rights}

Codetermination rights matter, because they determine how much access workers have to management decisionmaking. However, different statutory frameworks apply, and public, private and non-profit legal forms all have different mandatory subjects of consultation and stipulate different worker roles in governance. Public-sector codetermination rights are set by Länder, but additional rights are often built into restructured hospitals through collective agreements or enabling legislation, sometimes associated with a switch to a private legal form. State and local governments thus have much flexibility in setting codetermination rules.

Public-sector codetermination is limited to immediate workplace issues by the legal theory that elected parliamentarians, rather than the public-sector workforce, should be responsible for public service provision. Under public legal forms Anstalt or Körperschaft des öffentlichen Rechts (AöR or KöR, used for municipal and university clinics, respectively), codetermination does not extend to 'strategic' decisions around investment and technology and there are fewer worker representation on supervisory boards than in the private sector. Hospitals with the private legal form Gesellschaft mit beschränkter Haftung $(\mathrm{GmbH})$, whether publicly or privately owned, fall under national private-sector codetermination rules, with more mandatory issues of consultation. Large GmbHs have parity representation on the supervisory board - i.e. half of the seats, but no veto power - and an Arbeitsdirektor responsible for personnel issues and nominated by worker representatives. The non-profit variant $(\mathrm{gGmbH})$ is weaker and has no requirement for parity or an Arbeitsdirektor. 
The three large for-profit chains have distinct enough industrial relations strategies that the roles of worker representatives vary significantly between them. These hospitals are all covered by the stronger codetermination rules associated with the GmbH form (although smaller subsidiaries doing service work usually fall under the size threshold for parity codetermination). During our research, ver.di was in the process of organizing collective bargaining and establishing codetermination organs within the private hospital companies. With Helios they signed a national collective agreement in 2007 which stipulated almost the same conditions as determined by the public-sector agreement. Asklepios, after initially taking a hard-line approach in the dispute in Hamburg (and then negotiating a local agreement that mirrored the public sector), accepted the principle of multi-workplace bargaining. Negotiations, however, broke down when the company refused to negotiate an encompassing national company-wide framework. For its part, Rhön-Kliniken remains only willing to bargain at the hospital level (Gröschl-Bahr and Stumpfögger 2008).

Surprisingly, two of the hospitals in our sample with the most labour-management conflict are state-owned with a public legal form. Weak public-sector codetermination rights have led to the exclusion of worker representatives from management decision making. Stuttgart's municipal clinics (which were spun off into $A \ddot{R} R$ in 1999) and at the Charité in Berlin (which was a merger of three university hospitals and became in 2005 a $K \ddot{o} R)$, workers have struck to defend the link to national bargaining. In Stuttgart, this mobilization involved a strong element of support from local 'social networks', as trade unionists called them - citizens initiatives and worker-priests - supporting campaigns against speedups in service areas or for more funding for hospitals. At university clinics 
union influence is especially weak, because workers are represented as one of many interest groups on the governing bodies, which professors tend to dominate.

At state-owned hospitals with a private legal form, we observe two different patterns of trade unionism. The first we observe at the municipal clinics of Dortmund (a $\mathrm{gGmbH})$ and Vivantes in Berlin (a $\mathrm{GmbH})$, namely a strong pattern of social partnership. In Dortmund, trade unionists won a stronger form of codetermination than that required for the non-profit $\mathrm{gGmbH}$ form. They accomplished this by threatening a campaign that would have disrupted restructuring and by negotiating an alternative with the SPD-led local government. Before privatization, Hamburg had a functional equivalent. Because of its public legal form, it lacked an Arbeitsdirektor or supervisory board, but the complex deal that established the new organization also introduced a wide range of consultative mechanisms. These mechanisms were also established after a conflict, this time the occupation of a hospital that was to be closed. The second option, which we observe in Chemnitz, which is also a wholly-owned municipal $\mathrm{gGmbH}$, is that codetermination takes place at the absolute minimum level allowed under a non-profit legal form.

The notion that German codetermination rules limit within-country diversity does not apply to hospitals, where these rules vary depending on organizational form. Furthermore, those hospitals subject to strong statutory codetermination frameworks do not all have smoothly operating labour-management partnership, and in hospitals operating under weaker non-profit and public-sector rules, ver.di sometimes negotiates improvements in participation rights. The way that codetermination rights are used thus depends on other factors. 


\section{Local unemployment}

Unemployment rates matter for the mobilization potential of employees. As many East

German trade unionists argue in interviews, if workers are merely happy to have jobs, they are unlikely to mobilize against restructuring. If they have good chances of employment on the outside labour market, the level of fear should be lower and mobilization easier. This labour market effect is consistent with the impressions of national ver.di officials we interviewed and confirmed by the variation in our sample.

Our sample, like Germany, can be divided into two kinds of local economies. Dortmund, Erfurt, Chemnitz and Berlin - four locales hit very hard by deindustrialization - have had unemployment levels fluctuating between 13\% and 20\% from 1993 to 2008, with 15-year averages ranging between $16 \%$ and 18\%. Marburg, Hamburg, and Stuttgart, by contrast, which had either stable manufacturing sectors (Stuttgart), or enough new service employment to compensate (Hamburg and Marburg), had unemployment levels of between $5 \%$ and $13 \%$ over the same period, with 15 -year averages between $8 \%$ and $11 \%$ (Anonymous 2008).

In cities with higher unemployment, mobilization is more difficult, and most cases fall into the co-management or quiescence category. In the one exception, BerlinCharité, mobilization was not as sustained as in Hamburg or Stuttgart and the political structure more open than in Erfurt and Chemnitz. Although works councillors won a collective agreement linked to the national public-sector settlement - which is not selfevident in Berlin, since the Land itself has left the employers association and negotiated pay concessions with ver.di - they did not win the strong codetermination rights seen at Dortmund, Vivantes, or pre-privatization Hamburg. 
The pressure put on workers by high unemployment explains some of the eastwest divide in German trade unionism. However, eastern trade unionists are not all quiescent (at least not in Berlin), and western trade unionists are not all militant. Nor are all of the high-unemployment zones in the east; Dortmund is in the west. Finally, labourmarket pressures do not necessarily translate into low union membership density: membership is high in Chemnitz (probably due to the aggressiveness of management) and Dortmund (reportedly due to the city's tradition of coal and steel).

\section{Local politics}

The receptiveness of local politics to unions matters in their decisions about mobilizing workers and allies against restructuring plans. This is a rarely explored field in academic studies of German industrial relations, partly due to the widespread perception that the industrial relations system is centralized and partly due to the focus on large privatesector manufacturing firms. However, hospital privatization and restructuring is a matter for city- and county-level politics, and public-sector codetermination rules, hospital planning, and universities (and their clinics) are matters for Länder. Usually, SPD-led governments are more open to union influence, and conservative-led governments are more closed, although conservative politicians in Hessen and Berlin have chosen a more

pragmatic approach towards trade unions and left-of-centre politicians in Chemnitz have been unreceptive.

In some cities, unions have a long history of influence due to their tight connection to the SPD. This is most clearly the case in Dortmund, where politics are shaped by a history of coal and steel, high union density, and decades of uninterrupted 
SPD electoral dominance. Hamburg is also a traditional union stronghold, with strong, politicized trade unionists in the manufacturing and transportation industries by the harbour. Prior to their respective electoral defeats in 1999 and 2001, Social Democrats had led Hessen's and Hamburg's governments almost continuously since the end of World War II. In Berlin, unions have also had good connections in politics partly due to the moderation of local Conservatives. This influence improved after 2001 with the advent of a coalition of Social Democrats and former communists. In these places, while public-sector industrial conflict is not unheard-of, union embeddedness in elite networks makes it easier to settle disputes, and in some cases, like Hessen, union influence has persisted despite the coming of a conservative government. Under these conditions, trade unionists either take advantage of the chance to be co-managers or (in more difficult times) seek to reinforce their influence through the complex dance of

\section{Konfliktpartnerschaft.}

Other cities have little tradition of union influence. In the former GDR, for example, the networks of trade unionists, politicians and public administrators are quite thin. In Chemnitz, despite an SPD mayor and trade unionists in the three largest party groups on the city council, unions have very little influence in public-sector restructuring. In Erfurt from 1990 to 2006 the mayor was from the conservative party and never established working relations with trade unionists. Similarly, in parts of the West, such as Stuttgart, local politics are dominated by conservatives, and the left is on the outside. In these places, politicians have little fear of taking on trade unions, and unions either fight back creatively, as in the social movement unionism seen in Stuttgart or post-2001 
Hamburg, or counsel workers at an individual level on how to cope with the effects, as in Erfurt and Chemnitz.

In the hospitals in our sample, state and local politics have shaped what trade unionists can accomplish. Some important decisions, such as whether to privatize, outsource, or leave the employers association, are left to the political and managerial sphere and not subject to codetermination. In this sense, the institutional frameworks governing worker participation and pay setting are locally chosen. Consequently, there are important moments in which national institutions of codetermination or sectoral bargaining provide little assistance to trade unionists. Where unions have retained strong traditional channels of influence, as in Dortmund or Berlin-Vivantes, labour-management partnership has been possible, at times with an element of conflict. Elsewhere, these channels have broken down, as in Hamburg, or never existed, as in most of the east and conservative-dominated parts of the west. In the latter places, unions built alternative forms of pressure or simply retreated.

\section{Implications for policy and theory}

In German hospitals, the effects of market making are far reaching. The state has attempted to raise capital investment by privatizing hospitals and slow cost increases by altering the reimbursement formulae used by insurers. These policies have encouraged the rise of for-profit hospital chains and led to greater transparency in pricing, leading to intensified cost-based competition between hospitals. As competition has intensified, managers have come under ever more pressure reduce costs and increase revenues. In this labour-intensive industry, this means treating more 'cases' with fewer employees, in 
some cases on lower pay. Although this is not exactly a zero-sum game, it is also not a fertile ground for mutual gains between insurers, hospitals, and workers. In general, the market's effectiveness as a way to cap costs undermines ver.di's bargaining power: we see concessions both in cases of partnership and conflict. Concessions have been especially deep in easy-to-outsource support services such as cooking and cleaning, which has lead to greater pay inequality. While the causal chain between market construction and workplace change is complex, it is also robust: most actors refer back to it in explaining their actions.

Setbacks in collective bargaining notwithstanding, we do find some evidence of union revitalization. In some of the cities we visited, hospitals were the largest employers and sites of creative campaigns and massive membership gains. Privatization did not lead to deviation from the sectoral agreement where ver.di was well organized. At the national level, ver.di built on this success by establishing national collective bargaining at one of the national hospital chains (Helios) and mobilizing members and allies to win a massive infusion of cash into the sector.

In German hospitals, intensified competition is not an uncontrollable outside force, but rather a steering mechanism used to contain costs. Under these conditions, the state and employers cannot be relied upon as agents of market correction. The problem is not only a gap between national institutions and local implementation. In our cases, the formal rules could not be read off of a national model, because employers and local policymakers were able to choose between statutory codetermination frameworks and between sectoral collective agreements. More fundamentally, some of the agents that had once built and sustained the German model were committed to a form of marketization 
that led to socially undesirable consequences (low-wage work) and political conflict. In these struggles, worker representatives took part in shifting and fragile coalitions at several levels, including that of the locale.

Although these cases are far from unique, the processes we describe vary in their generalizability. Within Germany, the disorganization of collective bargaining is hardly unique to health care, but can affect any sector with widespread outsourcing or price-based competitive pressures (Doellgast and Greer 2007). Germany may be in a class of its own in terms of the extent of the expansion of low-wage work since the mid1990s (Bosch and Weinkopf 2008; Grimshaw et al 2007); however, recent shifts to liberalize services across Europe may be bringing this trend to other countries (Lillie 2010). The locale also seems to matters in a wider range of countries for workers' capacities to resist these pressures. While strong qualitative evidence from a wide range of countries shows that such local factors explain union strategy (Dörre and Röttger 2006; Locke 1992; Tattersall 2010; Turner and Cornfield 2007) it is a matter for future research to examine whether they also matter, for example, in centralized states such as the UK. Less generalizable is the fragmentation of co-determination rules due to differing ownership structures. This mechanism is particular to those public services in Germany that operate as a 'mixed market' of public, nonprofit and private sector providers. Furthermore, within the German health care sector, these are large, well organized workplaces; ver.di therefore has better-than-average leverage in the renegotiation of wage setting and worker participation arrangements.

Market making, and resistance to it, deserve a more central place in policyrelevant social science. In many areas where markets do not exist, public policy is 
creating them, which may be leading to a shift of costs and risks from the rich and powerful to the poor and powerless. As we have documented above, this process has led to union revitalization in some large private service-sector workplaces. A general theory of how different kinds of markets affect workers and workplaces would be relevant beyond the field of industrial relations and could underpin alternative proposals for institutional design. 


\section{References}

Anonymous. (2007). Krankenhaus Barometer Umfrage 2007. Düsseldorf: Deutsches Krankenhausinstitut.

Anonymous. (2008). Arbeitslosenstatistik. Nuremberg: Bundesagentur für Arbeit.

Anonymous. (2009). Statistical Annex of European Economy. Autumn. Brussels: European Commission.

Anonymous. (Various years). Grunddaten Krankenhäuser. Report. Wiesbaden: Statistisches Bundesamt.

Baccaro, L., Hamann, K. and Turner, L. (2003). The politics of labour movement revitalization: The need for a revitalized perspective. European Journal of Industrial Relations, 9: 119-133.

Beckert, J. (2007). The great transformation of embeddedness: Karl Polanyi and the new economic sociology. Discussion Paper 07/1. Cologne: MPIfG.

Benz, D. (2005). It takes a village to win a union: A case study of organizing among Florida's nursing home workers. Politics and Society, 33: 123-152.

Bispinck, R., Dribbusch, H., and Schulten, T. (2010). German Collective Bargaining in a European Perspective Continuous Erosion or Re-Stabilisation of MultiEmployer Agreements? Discussion Paper 171. Düssldorf: WSI.

Blum, K. and Offermanns, M. (2009). Krankenhäuser zwischen Innovations- und Kostendruck. Die stationäre Versorgung seit dem Jahr 2000. Das Krankenhaus, 101: 2095-3002

Böhlke, N. and Schulten, T. (2008). Krankenhäuser unter Privatisierungsdruck. Die Mitbestimmung, 6: 24-27.

Böhlke, N. and Schulten, T. (2009). Die Privatisierung von Krankenhäusern in Deutschland und ihre Auswirkungen auf Beschäftigte und Patienten. in, N. Böhlke, T. Gerlinger, K. Mosebach, R. Schmucker, T. Schulten (eds.) Privatisierung von Krankenhäusern. Erfahrungen und Perspektiven aus der Sicht von Beschäftigten, Hamburg: VSA Verlag, 97-122

Bosch, G. and Weinkopf, C. (eds) (2008). Low-Wage Work in Germany. New York: Russell Sage Foundation.

Brandt, T. and Schulten, T. (2008a). Privatisation and liberalisation of public services in Germany: the example of the postal and the hospital sector. In M. Keune, J. Lescke, A. Watt (eds.) Privatisation and Marketisation of Services - Social and Economic Impacts on Employment, Labour Markets and Trade Unions. Brussels: ETUI. 
Brandt, T. and Schulten, T. (2008b). Auswirkungen von Privatisierung und Liberalisierung auf die Tarifpolitik in Deutschland. In T. Brandt, T. Schulten, G. Sterkel and J. Wiedemuth (ed.) Europa im Ausverkauf. Hamburg: VSA-Verlag, 68-91

Brinkmann, U. and Dörre, K. (2008). Die neue Unternehmenskultur - Zum Leitbild des „Intrepreneurs“" und seinen Implikationen. In U. Brinkmann, K. Krenn, and S. Schief (eds). Endspiel des Kooperativen Kapitalismus? Wiesbaden: VS Verlag für Sozialwissenschaften, 136-168.

Commons, J. (1909). American Shoemakers 1648-1895. The Quarterly Journal of Economics, 24:1, 39-84.

Deppe, H.-U. (2002). Kommerzialisierung oder Solidarität. Zur grundlegenden Orientierung der Gesundheitspolitik. In H.-U. Deppe and W. Burkhardt (eds.) Solidarische Gesundheitspolitik. Alternativen zur Privatisierung und Zwei-KlassenMedizin. Hamburg: VSA, 10-23.

Doellgast, V. (2009). Still a coordinated model? Market liberalization and the transformation of employment relations in the German telecommunications industry. Industrial and Labor Relations Review, 63: 3-23.

Doellgast, V. and Greer, I. (2007). Vertical disintegration and the disorganization of German industrial relations. British Journal of Industrial Relations, 45:1, 55-76.

Doellgast, V. and Holtgrewe, U. (2011). Path dependency on shifting ground: Limitations on creative action in German industrial relations. Work, Employment, and Society. Forthcoming.

Dörre, K. and Röttger, B. (2006). Im Schatten der Globalisierung. Wiesbaden: VS.

Frege, C. and Kelly, J. (eds) (2005). Varieties of Unionism. Oxford: Oxford UP.

Greer, I. (2008). Social movement unionism and social partnership in Germany: the case of Hamburg's hospitals. Industrial Relations, 47: 602-624.

Grimshaw, D. Jaehrling, K., van der Meer, M. Méhaut, P., and Shimron, N. (2007) Convergent and divergent country trends in coordinated wage setting and collective bargaining in the public hospitals sector. Industrial Relations Journal, 38: 591-613.

Gröschl-Bahr, G. And Stumpfögger, N. (2008). Krankenhäuser. In T. Brandt, T. Schulten, G. Sterkel and J. Wiedemuth (eds.) Europa im Ausverkauf. Hamburg: VSAVerlag, 165-180.

Hall, P. and Soskice, D. (eds.) (2001). Varieties of Capitalism. Oxford: Oxford UP.

Hassel, A. (1999). The erosion of the German system of industrial relations. British Journal of Industrial Relations, 37: 483-505. 
Holst, H. (2008). The political economy of trade union strategies in Austria and Germany: The case of call centres. European Journal of Industrial Relations, 14: 25-42.

Höpner, M. (2007). Coordination and Organization: Two Dimensions of Nonliberal Capitalism. Discussion Paper 7-12, Cologne: MPIfG.

Kirkpatrick, I. and Martínez Lucio, M. (1996). The contract state and the future of public management. Public Administration, 74: 1-8.

Krippner, G. (2005). Polanyi Symposium: A conversation on embeddedness. SocioEconomic Review, 2: 109-135.

Jaehrling, K. (2008). The polarization of working conditions: Cleaners and nursing assistants in hospitals. In Bosch, G. and Weinkopf, C. (eds.) Low-Wage Work in Germany. New York: Russell Sage Foundation, 177-214.

MacKenzie, R. and Martinez Lucio, M. (2005). The realities of regulatory change: Beyond the fetish of deregulation. Sociology, 39: 499-517.

Lillie, N. (2006). A global union for global workers: Collective bargaining and regulatory politics in maritime shipping. London: Routledge.

Lillie, N. (2010). Bringing the offshore onshore: Transnational production, industrial relations, and the reconfiguration of sovereignty. International Studies Quarterly, 54:3, 685-706.

Locke, R. (1992). The decline of the national union in Italy: Lessons for comparative industrial relations theory. Industrial and Labor Relations Review, 45: 229-249.

Marrs, K. (2007). Ökonomisierung gelungen, Pflegekräfte wohlauf? WSI-Mitteilungen 60: 502-507.

Müller-Jentsch, W. (ed) (1999). Konfliktpartnerschaft. Akteure und Institutionen der industriellen Beziehungen. München: Mering.

Nissen, B. (ed.) (2002). Unions in a globalized environment. Armonk, NY: ME Sharpe.

Rehder, B. (2003). Betriebliche Bündnisse für Arbeit. Frankfurt: Campus.

Rehder, B. (2006). Legitimitätsdefizite des Co-Managements: Betriebliche Bündnisse für Arbeit als Konfliktfeld zwischen Arbeitnehmern und betriebliche Interessenvertretung. Zeitschrift für Soziologie, 37: 227-242.

Sako, M. and Jackson, G. (2006). Strategy meets institutions: The transformation of management-labor relations at Deutsche Telekom and NTT. Industrial \& Labor Relations Review, 59: 347-366.

Simon, M. (2007a). Das deutsche DRG-Fallpauschalensystem: Kritische Anmerkungen zu Begründungen und Zielen. Jahrbuch für Kritische Medizin, 44: 41-63. 
Simon, M. (2007b). Stellenabbau im Pflegedienst der Krankenhäuser: Eine Analyse der Entwicklung zwischen 1991 und 2005. Report. Hannover.

Simon, M. (2008). Das Gesundheitssystem in Deutschland. Bern: Verlag Hans Huber

Streeck, W and K Thelen. (2005). Beyond Continuity. Oxford: Oxford UP.

Tattersall, A. (2005). There is Power in Coalition: A framework for assessing how and when union-community coalitions are effective and enhance union power. Labour and Industry, 16: 97-114.

Turner, L. (1991). Democracy at Work. Ithaca: Cornell UP.

Turner, L. and Cornfield, D. (eds.) (2007). Labor in the New Urban Battlegrounds. Ithaca: ILR Press.

Turner, L. (2009). Institutions and activism: Crisis and opportunity for a German labor movement in decline. Industrial and Labor Relations Review, 62: 294-312.

Wendl, M. (2008). Die Krankenhäuser in der 'Lohnnebenkostenfalle' - Über die Transformation öffentlicher Krankenhäuser in kapitalistische Unternehmen. Sozialismus, 7-8: 41-46. 
Table 1. Sample and sources

\begin{tabular}{|c|c|c|c|c|}
\hline Name & $\begin{array}{l}\text { Employees } \\
\text { in } 2007\end{array}$ & Owner & How and when formed & Data gathered \\
\hline $\begin{array}{l}\text { Vivantes Netzwerk } \\
\text { für Gesundheit } \\
\text { GmbH }\end{array}$ & 13,500 & Land Berlin & $\begin{array}{l}\text { Municipal clinics merged into an } \\
\text { autonomous subsidiary in } 2001\end{array}$ & 11 interviews \\
\hline $\begin{array}{l}\text { Charité } \\
\text { Universitätsmedizin } \\
\text { Berlin }\end{array}$ & 12,800 & Land Berlin & $\begin{array}{l}\text { University clinics merged into a } \\
\text { closely held agency in } 2003\end{array}$ & 3 interviews \\
\hline $\begin{array}{l}\text { Asklepios Kliniken } \\
\text { Hamburg GmbH }\end{array}$ & 8900 (FTEs) & $\begin{array}{c}\text { Asklepios } \\
\text { Kliniken } \\
\text { GmbH } \\
(74.9 \%)\end{array}$ & $\begin{array}{l}\text { Municipal clinics merged in } 1995 \\
\text { and privatized in } 2005\end{array}$ & $\begin{array}{c}20 \text { interviews; } \\
\text { participant } \\
\text { observation; } \\
\text { workshop } \\
\text { presentation } \\
\end{array}$ \\
\hline Klinikum Stuttgart & 6400 & $\begin{array}{l}\text { City of } \\
\text { Stuttgart }\end{array}$ & $\begin{array}{l}\text { Municipal clinics merged into a } \\
\text { closely held agency in } 1999\end{array}$ & $\begin{array}{l}6 \text { interviews; } \\
\text { workshop } \\
\text { presentation }\end{array}$ \\
\hline $\begin{array}{l}\text { Klinikum Dortmund } \\
\text { gGmbH }\end{array}$ & 4200 & $\begin{array}{c}\text { City of } \\
\text { Dortmund }\end{array}$ & $\begin{array}{l}\text { Municipal clinics merged into an } \\
\text { autonomous subsidiary in } 1999\end{array}$ & 4 interviews \\
\hline $\begin{array}{l}\text { Universitätsklinikum } \\
\text { Gießen und Marburg } \\
\text { GmbH }\end{array}$ & 4000 & $\begin{array}{c}\text { Rhön AG } \\
\text { (95\%) }\end{array}$ & $\begin{array}{l}\text { University clinics merged in } 2005 \\
\text { and privatized in } 2006\end{array}$ & $\begin{array}{l}10 \text { interviews; } \\
\text { workshop } \\
\text { presentation }\end{array}$ \\
\hline $\begin{array}{l}\text { Klinikum Chemnitz } \\
\text { gGmbH }\end{array}$ & 3710 & $\begin{array}{l}\text { City of } \\
\text { Chemnitz }\end{array}$ & $\begin{array}{l}\text { Municipal clinics merged into } \\
\text { autonomous subsidiary in } 1994\end{array}$ & 6 interviews \\
\hline $\begin{array}{l}\text { Helios Klinikum } \\
\text { Erfurt GmbH }\end{array}$ & 2000 & Helios AG & $\begin{array}{c}\text { Municipal clinics privatized in } \\
1997\end{array}$ & 2 interviews \\
\hline
\end{tabular}


Table 2. Types of worker representation

\begin{tabular}{lcccc}
\hline Degree of... & $\begin{array}{c}\text { Konflikt- } \\
\text { partnerschaft }\end{array}$ & $\begin{array}{c}\text { Social- } \\
\text { movement } \\
\text { unionism }\end{array}$ & $\begin{array}{c}\text { Co- } \\
\text { management }\end{array}$ & Quiescence \\
\hline $\begin{array}{l}\text { access to } \\
\text { management }\end{array}$ & High & Low & High & Low \\
\hline $\begin{array}{l}\text { worker } \\
\text { mobilization }\end{array}$ & High & High & Low & Low \\
\hline $\begin{array}{l}\text { coalitions with } \\
\text { civil society }\end{array}$ & Medium & High & Low & Low \\
\hline $\begin{array}{l}\text { engagement } \\
\text { with justice } \\
\text { issues beyond } \\
\text { the workplace }\end{array}$ & Medium & High & Low & Low \\
\hline
\end{tabular}




\begin{tabular}{|c|c|c|c|}
\hline \multicolumn{4}{|c|}{ Table 3. Comparison of cases } \\
\hline & & \multicolumn{2}{|c|}{ local politics } \\
\hline $\begin{array}{l}\text { co-determi- } \\
\text { nation rights }\end{array}$ & $\begin{array}{l}\text { Unem- } \\
\text { ployment }\end{array}$ & Open to union influence & Closed \\
\hline \multirow[t]{3}{*}{ Strong } & Low & $\begin{array}{c}\text { Konfliktpartnerschaft: } \\
\text { Gießen-Marburg post-2006* } \\
\text { (private) }\end{array}$ & $\begin{array}{c}\text { Social-movement unionism: } \\
\text { Hamburg post-2001 } \\
\text { (private) }\end{array}$ \\
\hline & & $\begin{array}{l}\text { Co-management: } \\
\text { Hamburg pre-2001 } \\
\text { (public) }\end{array}$ & \\
\hline & high & $\begin{array}{l}\text { Co-management: } \\
\text { Dortmund } \\
\text { (public) } \\
\text { Berlin-Vivantes } \\
\text { (public) }\end{array}$ & $\begin{array}{l}\text { Quiescence: } \\
\text { Erfurt } \\
\text { (private) }\end{array}$ \\
\hline \multirow[t]{2}{*}{ Weak } & Low & $\begin{array}{c}\text { Konfliktpartnerschaft: } \\
\text { Gießen-Marburg pre-2006 * } \\
\text { (public) }\end{array}$ & $\begin{array}{c}\text { Social-movement unionism: } \\
\text { Stuttgart } \\
\text { (public) }\end{array}$ \\
\hline & high & $\begin{array}{l}\text { Konfliktpartnerschaft: } \\
\text { Berlin-Charité } \\
\text { (public) }\end{array}$ & $\begin{array}{l}\text { Quiescence: } \\
\text { Chemnitz } \\
\text { (public) }\end{array}$ \\
\hline
\end{tabular}


43

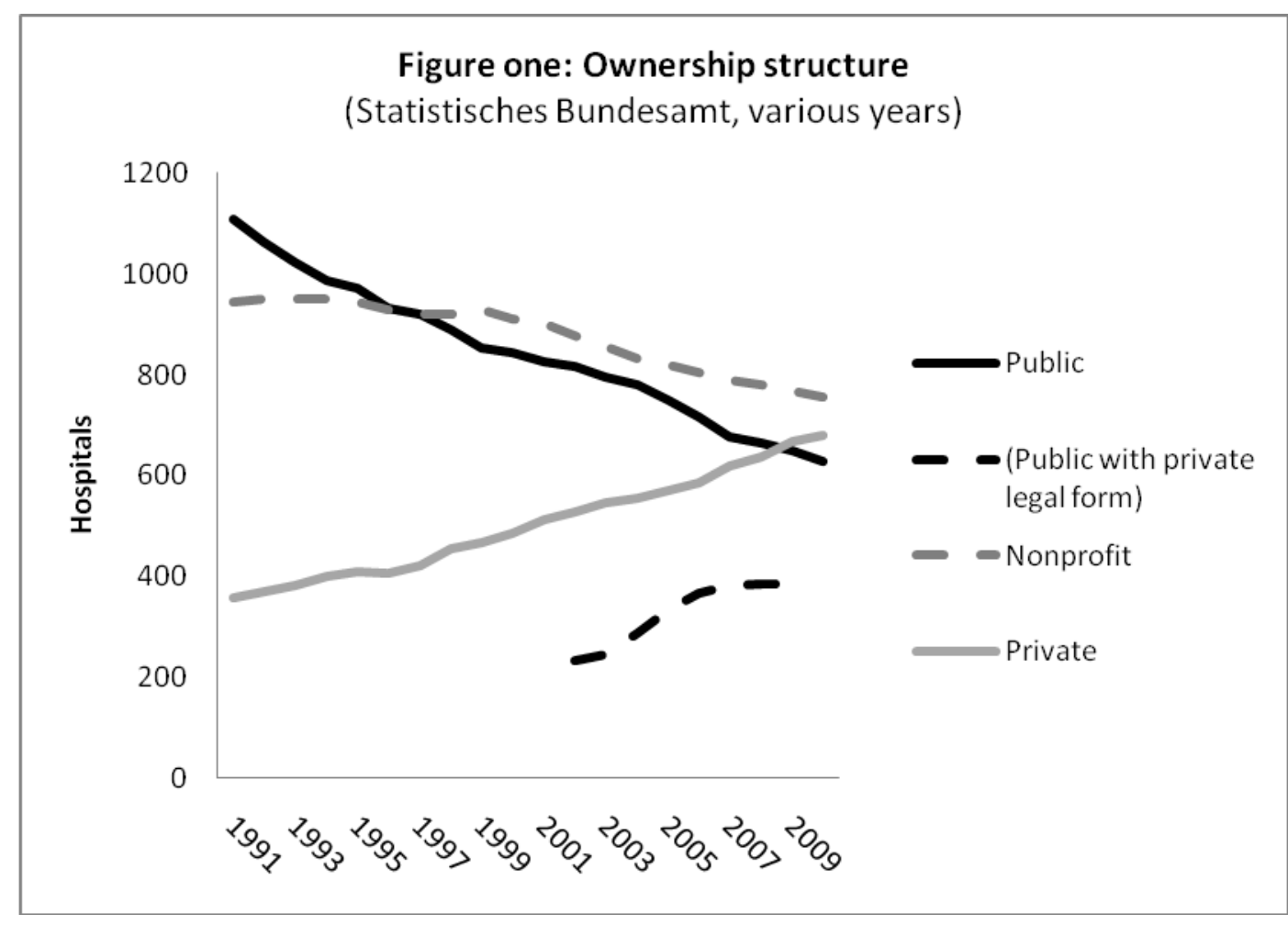




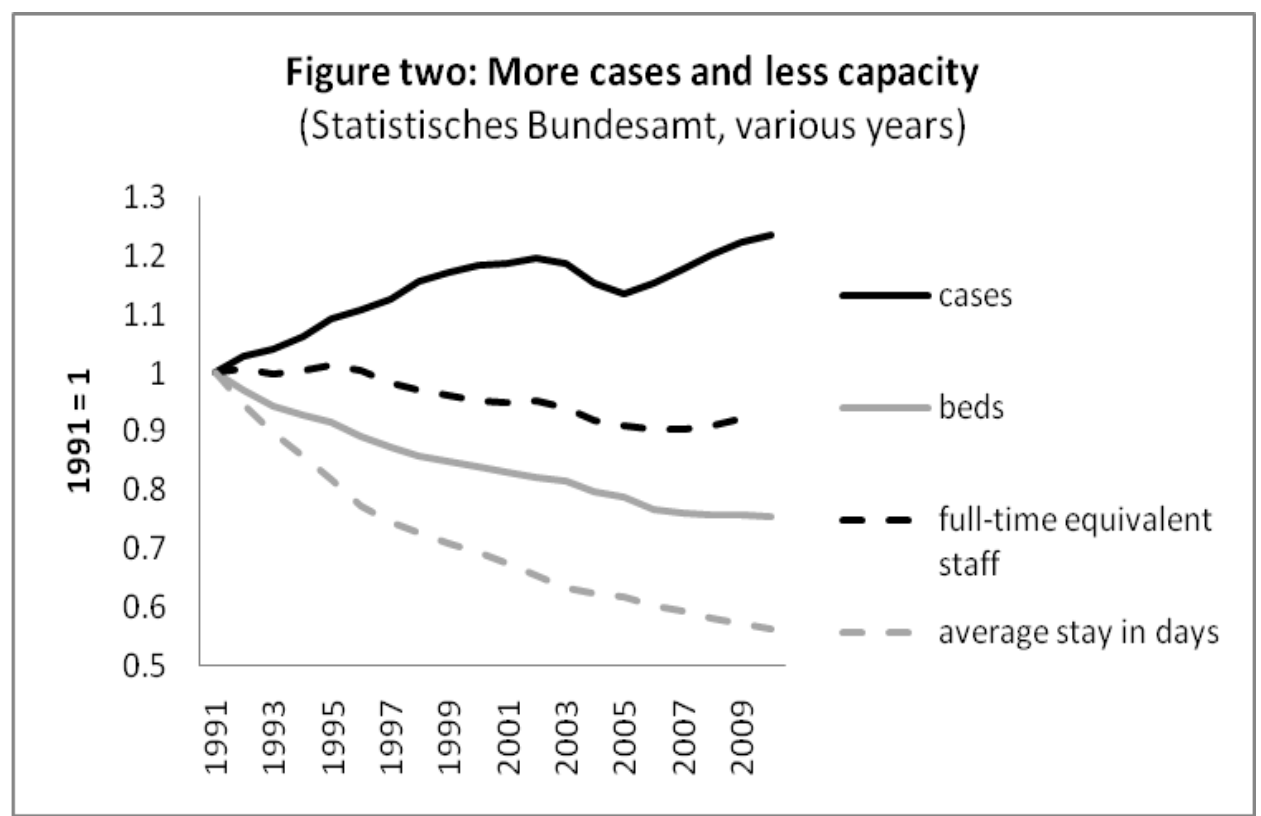


i 'Worker representation' in this paper refers to three kinds of actors. Gewerkschaft, or trade union, operating above the level of the firm; Betriebsrat, a formally separate works council body at the level of the workplace and firm under private and voluntary sector labor law; and Personalrat, a works council in a private-law company under public sector rules. In all of our cases, most works councillors are union members and work with union full-time officials.

${ }^{\text {ii }}$ The union is called the German Staff Association for Trade and Industry [Deutschen Handels- und Industrieangestellten Verband], an affiliate of the small Christian Trade Union Confederation [Christlichen Gewerkschaftsbund]. 